\title{
Abir's Enlightenment Revolution is the basic element leading to the end of the corrupt regime resulting from the poisoned Tunisian revolution 2011
}

\author{
Hassen Chaabani \\ Laboratory of Human Genetics and Anthropology, Faculty of Pharmacy, University of Monastir, 5000 Monastir, \\ Tunisia. E.mail: hassenchaabani@gmail.com
}

(Received 27 August 2021; Accepted 28 October 2021; Published 30 November 2021)

\begin{abstract}
Ten years after the launch of its 2011 revolution, Tunisia has reached a catastrophic socio-economic situation that confirms that none of major goals of this revolution have been achieved. Here, from an anthropological analysis of major events happened during this decade I reveal and discuss mysteries of this revolution, and I show how and why it got to her final stage. I qualified it as 'poisoned' because of clandestine interventions from some foreign countries that were able to steer it on a corrupt and dangerous path from the very beginning. In fact, although it was started by young people who have no political and ideological affiliation, many opportunist politicians rode its wave and given a false revolutionary label to their parties. One of these parties, 'Ennahdha', in a clear relationship with some countries, very likely got secretly considerable funds. The use of these moneys, coupled with dissemination of religious misinformation, during the pre-elections period permitted this party to be the first to come to power. Since then, it began (1) to support secretly those who perform the corrupt instrumentalization of Islam leading to terrorism and obscurantism, (2) not to apply laws that conflict with its interests, and (3) to develop corruption through wide networks spread in most of the national institutions particularly in judicial and security sectors. This has ensured it permanent influence over the major joints of the State even if it does not have the highest representation in the Government. At the end of this despaired decade, a glimmer of hope appeared with the emergence of the wonderful leader 'Abir Moussi' who called for Enlightenment Revolution. Her heroic struggle is the basic element leading to the end of the poisoned revolution 2011 and the resulting corrupt regime, which was mainly fabricated and dominated by Ennahdha, the last dangerous stronghold of the World Brotherhood Sect. I end this study by presenting recommendations aimed at eliminating the corrupt instrumentalization of Islam and preventing its return.
\end{abstract}

Key words: Poisoned Tunisian Revolution 2011. False democracy. Corruption. Terrorism. Corrupt instrumentalization of Islam. World Brotherhood Sect. Abir Moussi. Abir's Enlightenment Revolution 2020. Abir's heroic struggle. Free Islamic thought. 


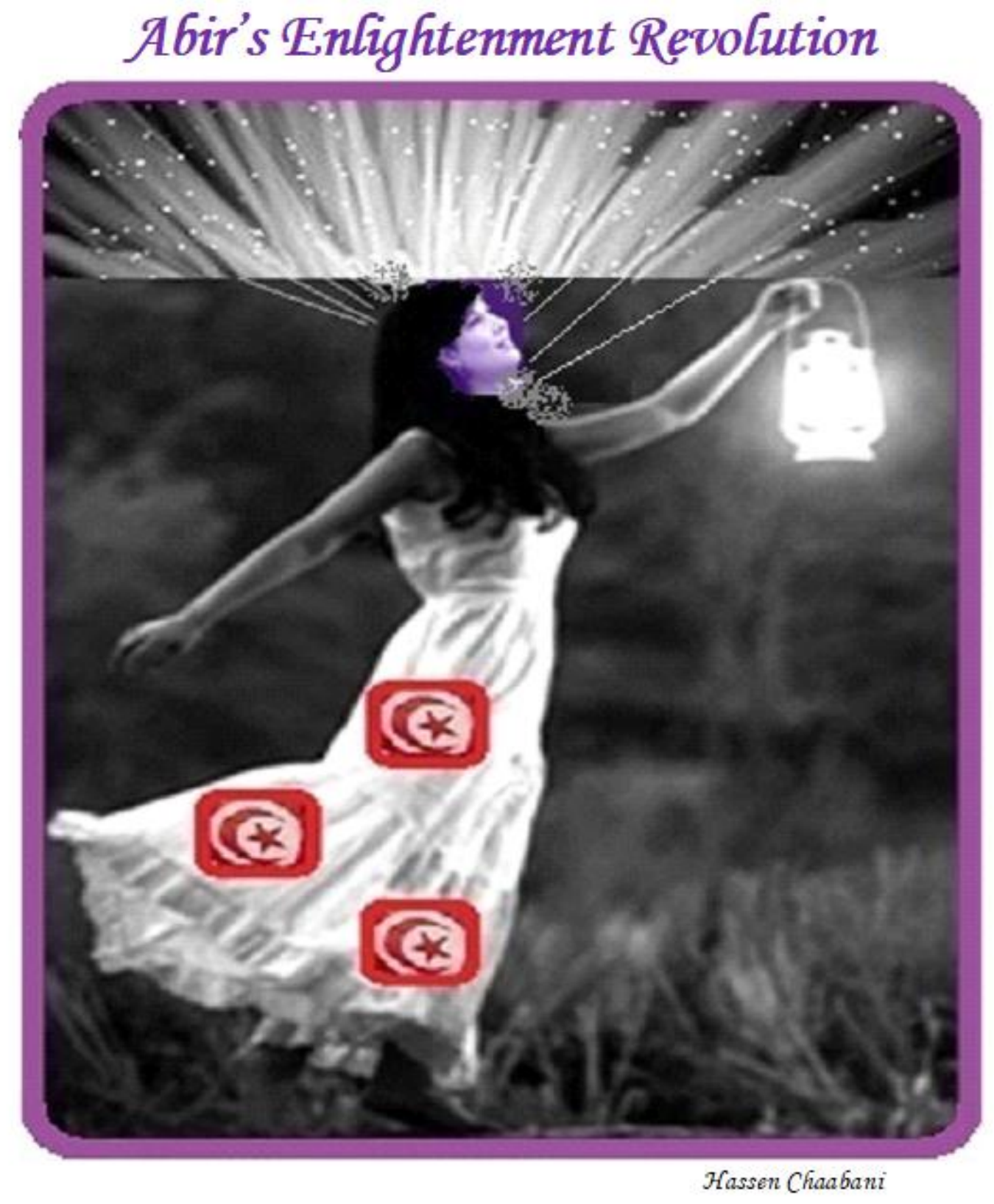

A picture symbolizing the leader Abir Moussi calling for Enlightenment Revolution

She is ripping the darkness of a frightening night with the light of a lantern (symbol of revolution's enlightenment) without caring about the dangers of the wolves around her 
In my previous study (Chaabani 2017) I have presented and discussed particularities and problems of the Tunisian Revolution 2011. Here, from an anthropological analysis of main political events happened during the last decade, I explain and discuss facts and mysteries of this revolution, and clarify how and why it got to its final phase.

I begin by presenting a rapid overview on its major phases, while showing how it has been poisoned since the beginning. Then I present the main reasons that led to the current disastrous general situation of Tunisia, demonstrating how a false democracy could be built on large networks of corruption. In a third section I evoke the issue about arguing whether or not this poisoned revolution is a real political revolution. The final section concerns the emergence of Enlightenment Revolution headed by Abir Moussi, where I show how her heroic struggle is the basic element leading to the end of the poisoned revolution 2011 and the resulting corrupt regime, which was mainly fabricated and dominated by Ennahdha, the last dangerous stronghold of the World Brotherhood Sect. To eradicate the dangerous phenomenon of corrupt instrumentalization of Islam and to prevent its re-emergence by followers of this sect and those of other political religious groups, I end this study by presenting rigorous suitable recommendations.

\section{Overview on the major phases of the revolution from 2011 to 2021}

At its beginning, the Tunisia revolution 2011 appeared as has three major particularities: the young age of the revolutionaries, the independence of their action, and their nonviolence. On the basis of these particularities I have designated it "Free, Youth Revolution" (Chaabani 2017) and considered it as represents a new step of paradigm change in the history of political revolutions. But unfortunately, as I explain in the following, the analysis of the main political events happened during its decade confirms that this revolution was poisoned, since its launch, by dragging it into a corrupt path.

\section{The first phase: its rapid unexpected accomplishment}

The first stage of the revolution 2011, related to the ending of Ben Ali's regime, was rapidly and successfully happened thanks especially to the following factors:

1. Features of revolutionaries: Revolutionaries who initiate the revolution are young, spontaneous, and nonviolent. Their willingness and their ability to use the most modern means of communication led to the Group's strength and gave the capacity to break 
down the barrier of fear. Their independence from political and religious leaderships and their general social demands make the most Tunisians support them.

2. The ethnic and cultural homogeneity of the Tunisian population has protected efficiently the beginning of this revolution against any risk of ethnic clashes.

3. The general environment of the country is ready for such a revolution:

- A dissatisfying economic picture with relatively high rates of unemployment and poverty in several regions of the interior. - The politic Ben Ali's ruling party (Democratic Constitutional Rally) was at the lowest level of weakness. - The security corps and the army are dissatisfied and they prefer to do not confront the people.

4. Two facts support secret external interventions during this first stage: the rapid and unexpected escape of the former President, and the fact that the killing of some hundreds of martyrs particularly after his escape was very likely carried out, at least partly, by mercenaries outside national security. In fact, as I explain below, the main objective of these secret interventions is not to facilitate the achievement of this first stage of the revolution as much as it is to steer the second long stage towards a corrupt path mainly thanks to the secret funds they send.

\section{Major events of the second corrupt long phase (2012-2021)}

Although the revolution was started by young people who have no political and ideological affiliation, many opportunist politicians rode its wave and given a false revolutionary label to their parties. One of these parties 'Ennahdha' party, belonged at the beginning, in the movement of the Brotherhood (Al Ikhwanjia sect) ${ }^{1}$, continues to follow the general ideology of this sect even though it is trying unsuccessfully to shun this fact ${ }^{1}$. Moreover this party, in a clear relationship with foreign countries, very likely got continual secret considerable external funds. The use of these funds coupled with dissemination of religious misinformation, during the pre-elections period permitted this party to be the first to come to power for only one-year mandate in a transitory Government. However, after the agreed-upon year, it refused to abandon power, and then after staying an extra year it accepted to start the dialogue and set conditions in exchange for leaving power: it should take a great part in the process of choice and ratification of the ministers of the new temporarily government that will supervise the

\footnotetext{
1 - The World Brotherhood Sect or the sect of Al Ikhwanjia is one of the political religious sects, which are known by their corrupt intrumentalization of Islam. It was founded in Egypt by Hassan al-Banna in 1928. It has been designated as a terrorist organization by many countries such as Bahrain, Syria, Russia, Egypt, UAE and Saudi Arabia. - See: Alarabiya 11/ 10/ 2013 (Historical relationship between Ennahda and the International Brotherhood). https://www.alarabiya.net/north-africa/tunisia/2013/10/11/
} 
first parliamentary and presidential elections. This permits it to approve at least the ministers of sovereign ministries who should be sympathizer and / or accept secretly that no serious investigation will be pursued into the cases of corruption, terrorism and political assassinations happened during their time in power 2012-2014.

Unfortunately other parties, particularly the new one 'Nidaa Tounis', ranked first according to opinion polls, accepted with some coercion these unsafe conditions that would favor the continuation of corruption and terrorism. But they consider their acceptance rather as the lightest damage because Ennahdha has threatened a civil war if these conditions are not accepted. In fact, this threat should not be ignored given that Ennahdha could have a secret apparatus ${ }^{2}$ responsible for the carrying out armed crimes and to make easier secret entries of weapons (Kortas 2013). These entries of weapons were already confirmed by the occurrence of armed terrorist incidents that led to killing several dozen people from Military, National Guard, Security Corps, or political sector.

Thus, after this unconvincing decision of acceptance, Ennahdha, staying without any serious follow-up to what it was accused of crime and corruption, continued to develop and reinforce the corruption in wider secret networks that, through its spread in the major government institutions, were severely damaged the economic system (see Yerkes and Muasher 2017). However these corrupt networks have ensured Ennahdha permanent influence over the major joints of the State even if it participates in the government with a few Ministers as its situation from the end of 2014 after the parliamentary and presidential elections that class 'Nidaa Tounes' as the first party in the parliament and Béji Caïd Essebsi, its leader, elected President of the Republic of Tunisia. Although ranked in second position, Ennahdha arrived to impose the first party to do with it a consensus to govern together. After three years thanks to its already developed large corrupt networks, Ennahdha had not only continued to exert directly and indirectly its power but also arrived to dissolve the Nidaa Tounes party like the case of other parties having done previous alliances with it.

In September-October 2019 the legislative and presidential elections (second elections since the adoption of the 2014 Constitution) taken place: In the presidential ones, the independent social-conservative candidate Kaïs Saïed leads the first round and

\footnotetext{
${ }^{2}$ See: - Althaydi M. 2018 (Nov 30). A secret apparatus for Tunisia's Ennahda. Al Arabiya News. https://english.alarabiya.net/views/news/middle-east/2018/11/30/A-secret-apparatus-for-Ennahda - Webdo tn 28/09/2019. Appareil secret d'Ennahdha : Mustapha Khedher au cœur d'un documentaire d'Al Arabiya. https://www.webdo.tn/2019/09/28/appareil-secret-dennahdha-mustapha-khedher-au-coeur-dun-documentaire-dalarabiya/\#.YEwGnJ1Ki00

- L'Economiste Maghrébin. 10 février 2021. Appareil secret : le comité de défense pointe du doigt Ennahdha. https://www.leconomistemaghrebin.com/2021/02/10/appareil-secret-le-comite-de-defense-pointe-du-doigt-ennahdha/
} 
the second round after which he won with $72.71 \%$ of the vote; while the legislative ones give rise to an extremely fragmented parliament: Ennahdha party comes in first, but in decline with less than a quarter of the seats. A new party 'Kalb Tunis' was classed second and headed by Nabil Karoui who has betrayed his supporters: before the election process he has promised to do not make any alliance with Ennahdha and to fight against the poverty; while after the process he has done the opposite. In addition, he has a court case on suspicion of corruption that is still ongoing despite his spending many months in prison, and recently he was arrested for illegal entry into Algerian territory ${ }^{3}$. On the other hand, another new party 'Free Destourian Party' appeared distinguished from all other parties by its sincerity and dedication in defending the national interest, especially thanks to the wonderful speeches of its leader Abir Moussi, and therefore this party represents the real opposition in the parliament.

\section{Political corruption is at the root of the current Tunisian tragic state}

Owing to the existence of many types of corrupt behavior it is not easy to give a general precise definition to the concept of corruption; however some definitions were considered: For example it is defined as the abuse of public power for personal gain (Neye 1967). The different forms of corruption could be grouped in two large categories 'upper-level' (involves high-ranking officials) and 'lower-level' corruption (belongs to the rest of people). Within the upper-level the term 'political corruption' was used in reference to corruption occurring at the policymaking stage particularly by presidents and ministers. However within the lower-level corruption, or public corruption, the terms bureaucratic or administrative corruption were used for people working in function of the public official or private Institutions (for review see Morris 2011).

For an anthropological view, the concept of corruption seems more complex and would be considered as a form of exchange in society between persons particularly at the way which they connect with the State institutions (e. g., Haller \& Shore 2005). Thus, studies done on one of its aspects separately (such as legal, political or economic aspects) are necessary but are not enough because of the complexity of this issue that requires the search for its original cause (s). Here I present corruption that occurred in Tunisia during the last decade showing how its root cause is mainly a combination between politics and a bad rare cultural phenomenon. As I explain in the following,

\footnotetext{
3 See MorningExpress, 05/09/2021, The Karoui brothers in detention at El Kedia prison in Constantine. https://morningexpress.in/the-karoui-brothers-in-detention-at-el-kedia-prison-in-constantine/
} 
among bad rare phenomenoms included in the culture of Muslims' civilizations is the serious attempts to mix religion and politics that could lead to what I call 'corrupt instrumentalization of Islam'. This, if it is adopted by who have the power, lead to a dangerous development and spread of all kinds of corruption associated to the emergence of terrorism and obscurantism. Effectively here I will show how Ennahdha, the first party arrived to power, already believes to the corrupt instrumentalization of Islam and encourage it secretly, exploited the existing corruption and develop and spread all kinds of corruption from the upper to the lower-level through extensive networks.

In the following examples I show how this political corruption is founded and developed particularly during the period 2012-2014, and persisted until 2021 and how its negative effects pile up from year to year, like a snowball get bigger and faster when it rolls down the slope. Moreover, through these examples I explain how political corruption has led to an increase in public corruption (lower-level corruption) and how it persisted during a decade under the control of the same party.

\section{Examples of political corruption in the judicial sector}

I begin by this sector given its great impact on the stability and prosperity of societies, namely as stated in the famous saying of the great historian and thinker Ibn Khaldoun "Injustice heralds the destruction of urbanization" 4 . Since the 2011 elections, political corruption in the judicial sector was developed. This is summarized in the declaration of Maitre Ridha Al-Radawi 5 "Law 67, which organizes the judiciary sector, was dropped after the revolution. Therefore the Minister of Justice, one of the leaders of Ennahdha, who took office after the 2011 elections, became the only one who controls the corps of judges: he dismissed about 80 judges without investigation or verification, then he made a series of judicial appointments in sensitive posts for the benefit of who are proEnnahdha; while he banishes those who cling to their independence". Such corrupt decisions, coupled with complementary ones made in the security sector ${ }^{5-6}$, led to a serious ambiguity and breaches at the security and judicial levels. Hence during the period (2012-2015) the most heinous terrorist incidents and political assassinations took place such as the assassinates of the two prominent politicians, martyrs Chokri Belaid

\footnotetext{
5 Ibn Khaldoun A. 1377. El Muquaddima. http://www.maaber.50megs.com/books/ibnkhaldoun.pdf Tunisian judiciary and exploiting it for its benefit. https://www.independentarabia.com/node/136096

${ }^{6}$ See the report in Nawaat Magasine, 31 juillet 2013. Investigation: "Neutralizing the Ministry of Interior", or how Ennahda penetrated the security apparatus. https://nawaat.org/2013/07/31/
} 
and Mohammed Brahmi that remains unresolved until nowadays: Despite the partial disclosure of terrorists who carried out the killings, those who planned and / or supported these killings have not yet been officially determined! However, some conflict within the judiciary highlights the excesses committed in these two assassinates and some clues showed that Ennahdha headed by Ghannouchi, having the power during this period, beside its complete morale responsibility, is accused of secret involvement in these two assassinates ${ }^{7-8}$. This accusation is supported by Tunisians who in their protests chanted, among other slogans, 'Oh Ghanouchi, oh ripper, oh killer of souls' (in Arabic 'Ya Ghannouchi.. ya saffah..ya Quattal larouah')'.

Moreover, a huge number of terrorism-related cases whose files have been manipulated and sealed or stuck in absence of 'a real supreme council for the judiciary' whom the establishment, delayed on purpose, took place only at the end of 2016. Since, although many patriotic judges began to make a tremendous effort to revive this sector and ensure its independence, they found serious opposition and difficulties made by a network of judge pro-Ennahdha. However, since 2020, thanks to her ongoing struggle, the leader Abir Moussi recalled the known corrupt and dangerous acts of Ennahdha and revealed recent ones. This has encouraged the patriotic judges to go deeply in their efforts and a first important decision has been made: the Disciplinary Council of the Supreme Council of the Judiciary, taken in July 13, 2021, suspends the former prosecutor of the Republic and judge, Bashir Akremi, accused of hiding terrorismrelated files, and transfers his file to the public prosecutor, under the court of first instance of Tunis ${ }^{10}$. This effort continues and leads, in 20/08/2021, to the suspend of the first president of the Court of Cassation and the head of the constitutional law monitoring body, Tayeb Rashid, from his duties on charges, while referring his file to the Public Prosecutor's Office for investigation ${ }^{11}$. In addition, other judges have been accused in other cases of corruption ${ }^{11-12}$.

\footnotetext{
${ }^{7}$ La Presse de Tunisie 03/12/2020. Le conflit au sein du corps judiciaire met en évidence les dépassements commis dans l'affaire Belaïd-Brahmi. https://lapresse.tn/80367/ppdu-le-conflit-au-sein-du-corps-judiciaire-met-en-evidenceles-depassements-commis-dans-laffaire-belaid-brahmi/

$\overline{8}$ See the report of Kasmi Abir in Business News Arabi 19 /03 / 2021. New details in Choukri Belaid case - security collusion and planning of the Islamic Party. https://ar.businessnews.com.tn/

9 e.g. see Video in https://www.tunisiefocus.com/ \& http://www.kapitalis.com/anbaa-tounes/2021/02/27/

10 See : webdo 13/07/2021. Tunisie : Le juge Béchir Akremi suspendu https://www.webdo.tn/2021/07/13/tunisie-le-juge-bechir-akremi-suspendu/\#.YO6tqegza00

${ }^{11}$ See : Business News. 20 August 2021. Taïeb Rached suspend. https://www.businessnews.com.tn/Ta\%C3\%AFebRached-suspendu-et-son-dossier-transf\%C3\%A9r\%C3\%A9-au-parquet,520,111383,3

12 e.g. see: Africa, News, Tunisia. August 11, 2021. Tunisia arrests judge in possession of $\$ 0.5 \mathrm{~m}$ https://www.middleeastmonitor.com/20210811-tunisia-arrests-judge-in-possession-of-0-5m/
} 


\section{Examples of corrupt use of foreign funds in the electoral process}

The electoral process is among important elements of democracy and would be considered as easily corruptible:

- First, the details of electoral rules, if they are not rigorously chosen, could be at the root of the apparition of political corruption (Persson et al. 2003). Accordingly, in Tunisia the results of implementing the current electoral system indicate the need to change it because it leads to a mosaic parliament unable to perform its oversight role and a state of chaos and dispersion in the political scene.

- Second, even if most electoral rules were rigorously founded, the licensing rules on the use of large funds during the electoral period, the investigation of their origin, and the monitoring how they are used, represent a problem that has remained without convincing solutions. In fact this problem persists, in varying degrees and in different circumstances, in almost all world countries even those known as the most democratic ones. Other factors could also corrupt the electoral process often related to indirect or more and less concealed corrupt behaviors such as the giving and receiving of bribes.

In Tunisia during the first Constituent Assembly election 2011, although the most rules of democratic elections were more and less respected, an evident weakness appeared at the supervision of the origin and the use of party budgets: it is broadly noted that the Ennahda's electoral victory was mainly due to its evident superior financial capacities, which they were convinced came mainly from abroad (Kaush 2013). In fact some clues indicate that Ennahdha party, in a clear relationship with other countries particularly 'Qatar', got considerable secret foreign funds (e. g., Kirkpatrick 2011, Chesnot 2013, Medini 2014, Schafer 2015) the use of which had influenced particularly the result of the first Constituent Assembly election 2011 (Kirkpatrick 2011). Despite the lack of hard evidence for such funds and the practical ways of their use, the enormous expenses of Ennahdha party remain obvious. For example, unlike other parties, it is the first party to open offices in towns across the country and to establish all costly propaganda methods, and it is accused of buying votes through the distribution of money and / or provisions very likely indirectly via related associations (nongovernmental organizations) particularly in regions and quarters where the poverty rate is relatively high. In other words it benefited from the presence of some socio-economic inequalities in which financial or material favors can be easily used to 'buy' votes 
(Kaush 2013). However it is not possible to confirm the accomplishment of these financial traffics because they were done indirectly, often through opaque, uncontrollable channels as associations with false label. In fact since 2011, in addition of about a hundred of parties, thousands of new associations were emerged and remained financially unsupervised intentionally and / or due to the lack of effective monitoring capabilities.

\section{Examples of political corruption leading to harmful socio-economic repercussions}

At the socio-economic level, among the first corrupt political decisions accomplished since the beginning is that described by the finance minister Hassine Dimassi (Technocrat) after his resignation in the 27/07/2012. He declared that the major cause of his resignation resides in the fact that the majority of government members, belonged to Ennahdha party, pushed in a decision which will generate a serious and sudden increase in the expenditure of the State in comparison with its resources ${ }^{13}$. Namely he sound the alarm for declaring that the superior interests of the State were threatened ${ }^{13}$ : In a televised interview ${ }^{14}$, he explained that Ennahdha government decided, through a bill submitted to the council of ministers, to reinstate and compensate persons granted general amnesty. Thus, between mid-2012 and mid-2014, around 132000 employees have been assigned in posts often superior to their abilities and diplomas and often in surplus in different sectors of public service. Moreover, these employees, the majority of whom are activists or followers of Ennahdha, received compensation of the wages of all the precedent years for the released prisoners. Knowing that this great number of prisoners did not fight for Tunisia, but, in a relationship with foreign powers, they tried to reach power mainly through violence and terrorism encouraged by political religious ideologies. To hide partially and temporary the catastrophic consequence of their deplorable decision, corrupt Ennahdha's government members, among others, stopped temporary continuing the execution of all major projects and not to launch new projects.

Indeed, instead of such deplorable decision, there are several much more advantageous possibilities, which should help all unemployed Tunisian people without

\footnotetext{
13 e.g. see : * Tunisie - Démission de Houssine Dimassi : Le coup de grâce?! 30 Juillet 2012 Par : Ali Abdessalem. WMC Portail. Webmanager center.

https://www.webmanagercenter.com/2012/07/30/122797/tunisie-demission-de-houssine-dimassi-le-coup-de-grace/

* Hassine Dimassi, ministre des Finances: pourquoi j'ai démissionné. Leaders NEWS - 27.07.2012 https://www.leaders.com.tn/article/8976-hassine-dimassi-ministre-des-finances-pourquoi-j-ai-demissionne

${ }^{14}$ See the video https://www.facebook.com/buzzcamtvblvck/videos/963778271103714/
} 
unjust and corrupt social discrimination and without the creation of permanent damage at the national economic level: for example, by giving rapid loans to do little rapid projects and making rapid setting up of greater national or private development projects particularly in internal neglected poor regions; this should create countless productive jobs and revitalizing the economy while preserving the balance of public finances. But unfortunately the first priority of Ennahdha is to remain in power and prepare for the upcoming near elections by immediate rapid attracting of the largest number of voters even if it is at the expense of a destabilization of the economy.

However, towards these 132000 employees (often in unproductive jobs) one can ask if at least a great part of them could have a direct or indirect particular assignment with Ennahdha party? Indeed, in addition to be already followers of this party they know that thanks to its government they took the place of people who, having no criminal record and holders of high level of diplomas, have already passed several years waiting for a job. Therefore, very likely, they would not hesitate to carry out Ennahdha's orders even related to corruption. Such situation would lead to the formation of one of backgrounds on which wide secret networks of corruption were developed between upper and lower levels. Recent investigations indicate that this type of corruption have been continued through other ways especially that of the recruitment of innumerable employees' holders of falsified certificates ${ }^{15}$

In addition to this kind of corruption, several corrupt decisions were taken and applied and continued under the protection of making stupid government bills, or thanks to the absence of laws specific to some complex models of corruption, or considered them as simple wrongdoings do not amount to litigation. In addition all ministers of the 8 governments, following one another during about only 9 years, in response to their personal and partisan desire to remain in government for the longest time, they have not applied any radical reform or demanded the introduction of new laws that would serve the supreme interest of the country. Bearing in mind that what ministers have done reflects the political quarrels that are taken place in parliament and that often finished by achieving the interests of the party, Ennahdha, that arrived, through corrupt ways, to dominate the parliament. This general corrupt political situation has facilitated the occurrence of large-scale corruption through coordination between upper-level and

\footnotetext{
15 See Alchourouk, 26/08/2021, the Union of the National Security Territory of Tunisia revealed that the number of employees who have been forged by the falsification of certificates by 30 thousand seconded in the public service in the last 10 years. https://www.alchourouk.com/article/
} 
lower-level, and therefore, has gone beyond harming the economy to harm people's health, such as the case of importing rotten food ${ }^{16}$ and the environmental scandal of the illegal importation of household waste from Italy ${ }^{17}$.

Among the greatest economic problems resulting from such political corruption, I want present the phosphate crisis in Gafsa (a south Tunisian region) that, started from 2011, has been remained without resolution until 2020. This crisis led to the fact that Tunisia, once a leader in phosphate, must now import ${ }^{18}$. In fact, from 2011 the country has risen from 5th to 12 th in the world as a producer, while the mining basin is plagued by repeated social movements. This crisis and others in the South, such as the repeated blocking of oil sites, represent huge financial losses every year.

In fact, regions of south and those of the north-west of Tunisia are among the poorest areas where there were no signs of development. Since the beginning of the revolution, although the planned annual budget funds of the State, countless hits and loans granted from other countries and international organizations intending for promoting these marginalized and poor areas, any real development project has been achieved and consequently continual dangerous social movements have been emerged. In fact, the successive governments that alternated political power for the last 10 years have either intentionally want that this problem persists or there's a stronger power that indirectly prevents them from undertaking its resolution within a radical effective reform. However, as this problem persisted even with the change of successive governments the second eventuality would be the most probable; namely the persistence of such problem is due to a corrupt political will of the same direct and indirect authority (Ennahdha authority) uninterrupted from 2012. But one can ask why Ennahdha carries out such strange dirty corrupt policy?

To understand and reach a reasonable answer to this question we must firstly know the fact that although Ennahdha always try to appear as a normal modern party, its history and its present, through its declared and secret acts, show that it is rather a dangerous political religious sect that, as I will explain in the following section, is able

\footnotetext{
16 See: Nawel Mahmoudi : La cargaison de blé contaminé provient de l'Ukraine. 2 Avril 2021. La Presse. tn. https://lapresse.tn/42321/nawel-mahmoudi-la-cargaison-de-ble-contamine-provient-de-lukraine/

${ }^{17}$ See: Investigation: Italian waste: The vast corruption network behind the environmental scandal. Written by Aida Delpuech and IrpiMedia. Inkyfada, 9 March 2021. https://inkyfada.com/en/2021/03/09 investigation-waste-

$\frac{\text { corruption-italy-tunisia/ }}{18}$ See: - Le Monde, Afrique, Tunisie. 06 octobre 2020. La Tunisie, autrefois leader dans le phosphate, doit désormais en importer (par Lilia Blaise). https://www.lemonde.fr/afrique/article/2020/10/06/la-tunisie-autrefoisleader-dans-le-phosphate-doit-desormais-en-importer_6054994_3212.html

- Jeune Afrique Tunisie 22 avril 2021: à Gafsa, l'introuvable solution à la crise du phosphate (par Frida Dahmani). https://www.jeuneafrique.com/1159483/politique/tunisie-a-gafsa-lintrouvable-solution-a-la-crise-du-phosphate/
} 
to gain voices particularly within poor persons and / or more and less ignorant with fragile personality and thought. Therefore, Ennahdha can keep the power as much as it can keep and increase the poverty, ignorance, obscurantism, terrorism and political instability; while it could not survive in a country sufficiently developed and stable. And indeed, during this decade it has managed to maintain and even increase poverty and ignorance rates: - the degree of illiteracy in Tunisia increased for the first time since independence, reaching 19 percent in 2018, after it was 18 percent in $2010^{19}$, - the unemployment rate in Tunisia increased during the second third of 2020 to reach $18 \%$, compared to $15 \%$ during the first third of the same year ${ }^{20}$.

\section{Examples of corrupt instrumentalization of Islam}

Generally 'instrumentalizing religion' means 'the use of religion for political ends'. But when the religion is Islam I prefer to give the following more precise specific meaning: the use of some issues related to Islam after having distorted or altered them to what suits personal advantages and / or political goals. Thus, I prefer use the expression 'corrupt instrumentalization of Islam'. In fact, during the Muslims civilizations history, there are continual attempts to mix religion and politics. This lead to the accomplishment of interference between Islam and policy following two major corrupt models: (1) model of the political incorporation in Islam and (2) model of an introduction of Islam into policy that I just designated 'corrupt instrumentalization of Islam'. However before presenting the evident occurrence of the second in Tunisia from 2011, I will summarize the history of its emergence and that of the first model.

1. Model of political incorporation in religion and its disastrous impact:

The typical example of this model is a discreet incorporation of a political problem in Islam leading progressively the division of Muslims into two groups. This has been begun by the emergence of a political tendency called in Arabic Shia that was developed timidly from the dispute about the allegiance of the first Caliph (from CE 632). Within this dispute the founders of the Shia group believed that "Ali", being among the most known Prophet followers and the husband of the daughter of the

\footnotetext{
${ }^{19}$ See: Amel Helali, in Arabi (Tunis), 16/4/2018. Minister shocks Tunisians by announcing high illiteracy rate in the country. https://arabi21.com/story/1123241/

${ }^{20}$ See: SPUTNIK Arabic, 16.10.2020. In Tunisia... Unemployment rises to $18 \%$.

https://arabic.sputniknews.com/arab_world/202010161046863899
} 
Prophet, should be the most eligible to be the first Caliph. As this was not happened, the followers of Ali grew in number and their accumulating reactions led to a first great splitting of the Muslim people into two major denominations of Sunni and Shia ${ }^{21}$.

Although this split was originally strictly political it became progressively religious in nature ${ }^{22}$. As shows in the figure 1 , I consider that the two major communities of Islam belonged to two versions of Islam showing some differences between them, on the one hand, and between them and the original true one, on the other; because they contained change, distortion, myths, lies and false interpretations that accumulated and developed during long periods under the influence of two opposite trends characterized by contradictory political depth.

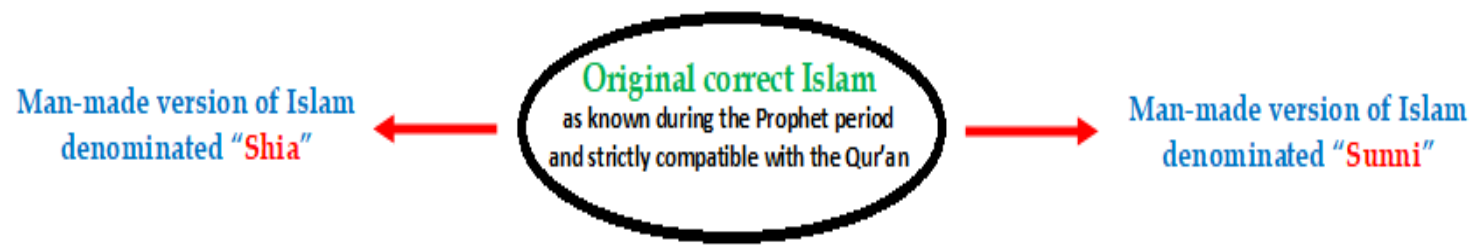

Fig. 1

In addition of this first event that had somewhat spoiled the unity of the Muslim nation in Sunni and Shia, some secondary divisions have been emerged within each of these two major denominations.

2. Model of introduction of religion into politics:

As stated above this model concerns what I have designated the 'corrupt instrumentalization of Islam'. On the basis of the period of its occurrence, I can present it as follows: (a) the corrupt instrumentalization of Islam that happened firstly during the last phase of Rashidun Caliphates era and (b) that happened after this period.

a) During the last phase of the Rashidun Caliphates era (from CE 632 to about 700), the first corrupt instrumentalization of Islam had been practiced by the Outsiders (in Arabic "Khawarij" that means the ones who deviated from mainstream Islam). In fact to prove causes permitting them to do political insurrection against the Caliphate system and reach the power they falsely interpreted some of the Qur'an verses and invented new considerations and laws incompatible with the principles of Islam. Moreover they had given to themselves the right to kill Muslims who do not accept their regulations. Thus, they had tried to violate the Free Muslim Thought that represents the

\footnotetext{
${ }^{21}$ Currently about 85-90 \% Sunni and 10-15 \% Shia (According to "Mapping the Global Muslim Population". Pew Research Center, 7 October 2009).

22 In fact, the Battle of Karbala ( CE 680), during which 'Husayn' the son of 'Ali' (the fourth caliph) was killed, played a central role in shaping the identity of Shia with own rituals and collective memory considering Husayn's suffering and death as a symbol of sacrifice in the struggle for right against wrong (for more detail see: Madelung, Wilferd. "Hosayn b. ali". Encyclopædia Iranica. Retrieved 2 November 2015).
} 
essence of Islam clearly proved in the Qur'an, and therefore to establish a mental slavery, which is far more sinister than physical slavery. They reached the pick of their terrorism at the end of era of Caliph Ali who was assassinated, in CE 661, by one of them. Since, they were strongly combated and disappeared progressively (Higgins 2004; Chaabani 2017).

b) From CE 700 to nowadays another way of corrupt instrumentalization of Islam was implemented, albeit it to varying degrees. In the different Muslim countries, its practice is generally toned down when a strong honest authority governs; while amplified as much as the governing authority is corrupt and dishonest. In fact, this way, somewhat different to the precedent, is mainly based on the emergence and development of the so called sciences of Shari' $a$ and Fiqh and their derivatives, and the emergence of men of religion under several designations such as Cheikh, Fakih or Aalim. Such designations, evidently anti-Islam, are very likely established with a discreet view to obtaining material, prestigious and authoritarian privileges similar to those of clergymen, monks, or priests already fabricated in other religions. Before given examples on this way of implementation of corrupt instrumentalization of Islam I should definite the so called sciences of Shari' ${ }^{23}$ and Fiqh ${ }^{24}$.

In fact, all writings of these so called sciences cannot be part of Islam: First, they are man-made, while Islam is only what is descended (during CE 610 - 632) from Allah via the angel Gabriel to the Prophet Mohamed, Salla Allaho Aleihi Oua Salim $(S A A O S)$, and registered without any change in the unique Book of Islam the 'Qur'an'. Additionally Muslims should take into account with a great prudence only the Prophet sayings 'Ahadith' in complete accordance with Qur'an because a great number of them

\footnotetext{
23 The term "Shari'a" is mentioned only one time in the Qur'an, as being the path marked out by Allah [Qur'an, 45: 18]. Namely Shari'a is the eternal, perfect path of truth and justice that no one can define or achieve; but honest humans, particularly real scholars, great thinkers and Jurists, in a given period and place could strive to establish rules and laws related to different major social issues. These rules and laws should respect the essence of Islam that could be deduced from a global deep explanation of Qur'an that one can summarize it in 'freedom of thought, good morals and the interests of the individual and society alike': The more these laws are in conformity with this essence, the closer they are to the ideal theoretical Path of God or Law of God or Shari'a. Accordingly, the Qur'an is not a book of laws, as narrow-minded Sheikhs want to convert it and therefore they invented laws that they considered as inspired from Qur'an and Prophet Sayings and they falsely designate them Schari'a. Reverse that, as I have previously explained: one of major processes, which would provide the super dynamism peculiar to the Qur'an, is that for each important social issue Allah does not provide an absolute legislative rule that Muslims must implement blindly as much as He would intend to familiarize Muslims to evaluate and compare advantages and disadvantages between different approaches of a given issue; and therefore Muslims preserve the flexibility to choose what is better good at both the personal and the societal levels in the context of their epoch (Chaabani 2019).

24 The so called science 'Fikh' and that of the person specialized in it 'Fakih' are never existed during the Prophet period and the post Prophet Period, but only the verb 'Tefakaha' was used in the expression 'Tafakaha fi addine' that means 'make an effort to understand the religion'. In addition during these periods, anybody, even among the known followers of Prophet who became the Caliphates after his death, has considered himself as more competent than others in the explanation of Islamic issues or Qur'an verses, because all Muslims should make an effort to more understand Islam and no one can confirm that he knows the accurate correct explanations of Qur'an verses.
} 
were altered intentionally or unintentionally, or not really said by the Prophet. Second what we call now Sharia and Fikh were not existed or even pronounced as terms during the period of Prophet Mohamed (SAAOS) or even during the post Prophet Period, Rashidun Caliphates era, from CE 632 until about 800.

According to Ibn Khaldoun, the Imam Ash Shafei (CE 767-820) was the first who began to establish what we call now sciences of Shari'a and Fiqh. Although this initiation came mainly as a response to the recommendation of the authority of his epoch, he accomplished his studies with prudence and good faith. But after his death this initiative was badly developed by considering as truth all ancient explanations and narrations and by adding other uncertain narrations, confusions, stupid fibs and injunctions as results of individual desire and tendency of narrow-minded men of religion (Cheikhs and Fokaha) in addition of a socio-cultural-political influence at different successive periods.

Expressing indirectly and softly his refuse to consider such writings among other known rigorous scientific fields, Ibn Khaldoun designated them Ouloum Ennakl 'sciences of transfer'. I consider this designation as a correct and intelligent one; because these writings represent mainly a transfer of ancient explanations often linked to uncertain narrations transferred verbally during long periods with unacceptable additions full of fibs and confusions. In this way, the academic professor Mohamed Talbi (Talbi 2015, 2016) called such strange sciences 'sciences of parrots' because the majority of men of religion repeat what they learn about these sciences without making any evident fruitful effort in thinking, analysis and criticism.

The narrow minded hypocrite men of religion try to fossilize the Qur'an text through their rejection of its innovative re-reading; while Allah requests all Muslims, particularly the great minds and specialists in different real rigorous sciences, at all time and everywhere, to interpret the Qur'an text. On the contrary, they welcome additions to their sciences of transfer given by those belonged to their sect (sect of men of religion, who are often narrow-minded or blinded by their own pride and worsen by their lies and hypocrisy). Although they have an evident lack of knowledge in all real sciences, they consider themselves as the only ones empowered to interpret the Qur'an. Hence, from the medieval period to nowadays some of them have added incorrect explanations that go with their stupid personal desire and political goals and invented stupid ideologies where they incorporated Islam in politics and laid the seeds of violence and terrorism. 
Therefore these sciences of transfer represent the background and the source of corrupt instrumentalization of Islam.

What happened during the last ten years (2011-2021) in some world countries represent good examples that show the highest degrees of catastrophic consequences of the implement of corrupt instrumentalization of Islam. In fact during this period a series of uprisings occurred in several Muslim countries such as Tunisia, Egypt, Syria, and Libya. These uprisings or revolutions (Arab Spring) have been moved towards bad corrupt ways mainly under the effect of external interventions. In fact enormous funds flow from abroad for the benefit of sects or parties having political religious ideologies. These external interventions contributed with other internal factors to the outbreak of civil war in some countries such as Syria and Libya where the funds flow was extended to arms flow. However the political religious parties, that of Muslim Brotherhood in Egypt and that of Ennahda in Tunisia, have been the first coming to power mainly thanks to the use of these dirty funds and the spreading false religious propaganda through corrupt instrumentalization of Islam during the pre-elections period. In Egypt thanks to the great brave Abdel Fattah al Sissi (actual President of Egypt) who, when he was Minister of Defense, and ultimately Commander-in-Chief of the Egyptian Armed Forces, has put an end to this dangerous situation since 2013 in response to great Egyptian protests. However, in Tunisia this dirty situation persists until 2021.

In fact, the major goal in common between all political-religious movements in Muslim countries, such as Ennahdha party in Tunisia, is to reach the possession of power. However, they show some differences particularly at the level of the degree and the timing of the use of violence. Their common tool is the corrupt instrumentalization of Islam, what we commonly designate in Arabic Attijara Bi Addine, dealing with religion ${ }^{25}$, following several methods aiming to perturb people's beliefs existing in the most sensitive and profound area of the human mind, then to try to enslave their minds by a stupid ideology which has nothing to do with Islam (Chaabani 2017).

One of these methods, applied by Ennahdha and other political religious groups, consists of making weird new words or misrepresenting others while manipulating their meaning. For example, the term "Islami", Islamist, is a relatively recent Arab word that does exist neither in the Holy Qur'an nor in ancient writings. It has been used recently by extremists for distinguishing themselves as 'Muslims of

\footnotetext{
25 In Arabic we often use a more general expression 'Ettijara bi Addin', dealing with religion, considering Islam as a commercial commodity that could be used after distortion aiming to obtain personal benefits particularly political ones. Therefore we call who implement the corrupt instrumentalization of Islam a 'religion dealer'.
} 
superior degree' and / or as 'representatives of Islam'. Through this weird term and its fabricated meaning, in complete contradiction with Islam $^{26}$, they aim to attract the maximum of people by given them this new so called privileged nomination if they follow their sect, movement or party. Namely this designation "Islamists" represents a label, through it, they spread their stupid political religious ideology particularly within young people who do not yet have sufficient details related to Islam and / or going by a fragile psychological situation (Chaabani 2017).

Moreover, these political religious extremists have fabricated the antonym of this term Islami vs. Ilmani: They consider all who do not follow them as a 'Ilmani' trying to disturb the Muslim thought and to divide Muslims in two groups 'Islamiin' and 'Ilmaniin'. In fact the designation 'Ilmani' derived from 'Ilmania',27 (scientism). This term, showing a little difference in pronunciation with the term 'Almania',27 (secularism), was used, on purpose instead the latter, by extremists to indicate a vague sense including both secularism and scientism because they want to consider secularism like scientism somewhat related to atheism. Thus, thanks to such wordplay, they can attract to their sect as many simple religious people as possible. Effectively, in Tunisia during the pre-selective periods, Ennahdha leaders had tried indirectly through their speeches to break the socio-cultural homogeneity of Tunisians implying that those who are not with them as Islamist ("Islami") should be an "Ilmani" (secularist and rather scientistic atheist). Unfortunately, particularly during the first election campaign (2011), many simple religious people had responded to this funny and silly attempt. But now after ten years of Ennahdha power, the majority of the Tunisian people were assured that Ennahdha is a corrupt disloyal sect and has nothing to do with Islam and morals.

Ennahdha applies another method that consists to spread secretly and indirectly its ideology through related organizations in exchange for their protection and providing funds. Among these organizations the branch of International Union of Muslim Scholars (IUMS), and hundreds of associations with contrasting labels such as charitable associations and / or Qur'an teaching schools; for example that of 'Reguab'

\footnotetext{
${ }^{26}$ First, in the Holy Qur'an, all who convert to Islam are only designated "Muslims" and only God can judge them based on their behavior and their degree of commitment to good morals. Second, only the Holy Qur'an and some assured prophetic hadiths represent Islam, so no one can represent Islam in order to replace God on earth or to be an intermediary between God and believers who must have a direct vertical relationship with God.

${ }^{27}$ The Arab word "Al Almania", derived from "Al Alam" (the World), was considered to be the translation equivalent of the term "secularism" that means the separation of government and political authority from religion. Political religious extremists have discreetly imposed a very small change in the pronunciation of the term "Al Almania" by "Al Ilmania" which has a different sense: it derived from the word "El Ilm" (science) and could mean "scientism": ancient ideology of who believes that sciences contain all real knowledge without recourse to supernatural belief, and therefore he could be atheist.
} 
(operated since 2012 outside the law and the State's educational curricula) where children learn dangerous behaviors falsely assigned to Islam, and even some of them are subject of sexual exploitation ${ }^{28}$. Thus through this method Ennahdha can prepare young with enslaved minds ready to execute even criminal acts.

This spread of political religious extremist ideologies was also done in advocacy tents and mosques through speeches of Imams or phony preachers. In a second step, within a secret system, only persons interested into their ideology will be invited, and after explaining and anchoring its details in their minds, some tasks could be assigned to them; while, more later, the execution of suicide attacks are given to selected ones who reach a psychologically fragile state coupled to blind implement ability.

From all these analyses and explanations, it is clear that the roots of the political-religious terrorism is not in Islam itself, but absolutely in narrow-minded hypocrite men of religion who, from their sciences of transfer full of wrong interpretations, confusions, myths and lies, have fabricated political religious dictatorial ideologies, which represent the most important potential seed of the political-religious terrorism that can sprout anywhere when favorable conditions emerge.

Although Ennahdha government (2012-2014) apparently seems as not implicated directly in terrorist acts, it was accused of having turned a blind eye towards the first steps leading to terrorism, but when innocent people were killed after the carrying out of the last step of terrorism, it declared that it was strongly against terrorist acts. In other words, Ennadha is against terrorist acts only after they happen! This is one of the ambiguities that have strongly characterized this party which always tries to present itself as a modern and moderate party with a religious reference. But the truth did not remain hidden for long and began to emerge by accusing Ennahdha of its indirect or secret relations with terrorists, through its interference in preventing their arrest, helping them escape, or pressuring the security and judiciary to acquit them when they were arrested $^{29}$, and even communicating with them if they are imprisoned: it is recently reported that parliamentarians from the Ennahdha movement were accused of making nightly visits to terrorist elements incarcerated in two prisons ${ }^{30}$.

\footnotetext{
${ }^{28}$ For more details see Kapitalis, Tunisia 2 / 2 / 2019 http://kapitalis.com/tunisie/2019/02/02/ecole-coranique-de-regueb-suspicion-dabus-sexuel-sur-les-enfants/

29 - Leaders, NEWS, 17.09.2012. Comment ‘Abou Iyadh' s'est échappé de la mosquée Al-Fath ! https://www.leaders.com.tn/article/9307-comment-abou-iyadh-s-est-echappe-de-la-mosquee-al-fath \& - Ar. African Manager 19/8/2014 https://ar.africanmanager.com/

${ }^{30}$ Liens présumés entre des élus d'Ennahdha et des terroristes incarcérés. Par Samir Dridi. La Presse. tn. 18/3/2021. https://lapresse.tn/65379/liens-presumes-entre-des-elus-dennahdha-et-des-terroristes-incarceres-qui-sont-lesdenonciateurs/
} 


\section{Does the so-called Tunisian Revolution 2011 is a real revolution?}

The issue of arguing whether or not the Tunisian Revolution 2011 is a real revolution has evocated some debate particularly from 2011 until 2017. Although many Tunisians think that such debate mainly represents a false problem, others insisted on giving their opinions that could be classed in two general opposed ones. Peoples aligned in the first, consider, on the basis of different reasons, what happened in Tunisia from 2011 has not rise to be designated revolution. On the other hand, peoples aligned in the second consider it as a revolution that does not yet reach the accomplishment of its major goals, but the majority of them from 2018 as all things become clearer have lost their optimism and changed their opinion.

Accordingly, I believe that now it is possible to take up the evident most reasonable and convincing position on this issue. This will be deduced from discussing the general conditions that allow to attribute the designation 'revolution' to a popular uprising and confronting them with what happened in Tunisia from 2011. In fact it is not possible to give an accurate general definition of what we can designate 'revolution' particularly from analyzing profiles of previous ones happened during different periods of the human populations history, because each revolution is influenced by a particular context of time and space. However, the extent of its true occurrence can be estimated from its results, namely from the degree of revolutionary change and from the way this change occurs and how long it lasts.

Hence this estimation appears more and less variable and reflects the diverse opinions of theorists of revolution. For example:

- Some of them argue that the post-revolutionary situation should be absolutely new and evidently different from the precedent, others consider that the revolution could be believable if it realizes a relative novelty (for review see Grosser 2016). In the same regard, Immanuel Kant presented different notions of the 'new', and joined together 'complete change' and 'thorough reform' (Kant 2006a [1795/96]).

- Besides, although some theorists argue that change would take place in a discontinuous fashion, others consider that successful revolutionary change would take place in a continuous or stepwise manner (for review see Grosser 2016). 
- Even the nature of the revolutionary change is discussed: while some thinkers support that revolution should concern mainly a cultural change (renovate the attitudes, convictions, education, morality, freedom of thought....), others consider that political change at institutional frameworks within which humans act and interact represent the major revolutionary change (for more details see Grosser 2016). However, Immanuel Kant would prefer the union of these two types of change by speaking about politicomoral change that, happened under a lowest degree of violence, would lead to a new better order guarantees, freedom, justice, and prosperity (Kant 2006b [1784]).

Taking into account all theses opinions on revolution criterions, I can propose the following brief definition of a modern political revolution: A popular uprising merits to be considered as a 'political revolution' only when a deep politico-moral change happens leading to a socio-economic and cultural progress. Does this definition agree with what happened during the first decade of Tunisian revolution 2011 ? Absolutely it is not. In fact during this period a questionable political change was built on corruption and in immoral political climate, no radical reforms were achieved, and the situation has been regressed from bad to worse to catastrophic at all levels. Therefore the so called Tunisia revolution 2011 is not lived up to be considered as a real political revolution. As I have already explained above, this is due mainly to the fact that it is poisoned and derailed from the correct path since its beginning. Moreover in the following I demonstrate how the questionable political change accomplished from 2012 has produced a false democratic system.

The term democracy comes from the Greek words 'demos' meaning people and 'kratos' meaning power, and therefore means rule by the people. However the carrying out of this principle is not merely a question of election of rulers by the people like the successive Tunisian governments' members want to pass, but it needs a general deep restructuring that should include the achievement of a new modern correct and suitable Constitution, a real independent judiciary, a rigorous system of voting and elections, and the imposition of the supremacy of law and the guarantee of freedoms. But this was not really happened in Tunisia during 2012-2021, and only a false fraudulent democracy appeared floating from time to time on a sea of corruption. I will point out the major problems that prove the falsity of this democracy as follows:

1. Problems of the new Tunisian Constitution 2014:

Within the first temporary parliament, thanks to the effort made by the patriotic minority of members many flagrant dangerous articles present in the first two drafts of 
the Constitution of 2014 were rectified. However, other problems remained in the final version because they are strongly supported by Ennahdha party members and their loyalists. These problems concern inaccurate vague articles or questionable unsuitable ones such as that of the political system, which is a strange hybrid parliamentary system not in line with the current socio-cultural-political environment in Tunisia. Accordingly, Professor of constitutional law, Sadiq Belaid, describes the political climate in Tunisia from 2012 as evidently most corrupt than it was before, and in turn he urges the need to change the present mined Constitution particularly the political system article ${ }^{31}$.

This issue of amending the political system has been raised in particular since 2016 by the late President Beji Caid Essebsi. Even the current president Kais Said has expressed his intention to move forward with the amendment of the current country's constitution. However the wonderful leader Abir Moussi does not only amending the political system but she already prepared a new Constitution project.

2. The supremacy of law has been called into question

- Abstinence of application of some major constitutional laws:

The Ennahdha and related parties' members represent the corrupt parliament majority: they have worked indirectly via all possible methods of corruption to delay the application of some major constitutional laws and related obligations that show some conflict with their personal and party interests. For examples: (1) the accomplishment of the supreme council for the judiciary was delayed on purpose to the end of 2016 after executing the major criminal acts particularly political assassinations, and (2) the Constitutional Court is not created until nowadays. This is at the root of several problems such as the fact that some independent higher commissions, despite their illegal and corrupt behaviors have continued to work, and the conflicts between the three heads of the State that remain without resolution. Moreover several other obligations were not accomplished such as the rectification or change of some ancient laws and the creation of new laws complementary to the general constitutional ones.

- Circumventing the implementation of the law:

About six thousands of files of terrorism-related cases have been manipulated and sealed or stuck and the Ennahdha leader is accused of political coverage of terrorists thanks to his loyal octopus inside the judiciary ${ }^{32}$.

\footnotetext{
31 See alaraby, 20/5/2020, Tunisia: "Third Republic" revives change of political regime, https://www.alaraby.co.uk/

32 See: Arab Observer, 30 /06/2021, Ghannouchi accused of political and judicial coverage of terrorists in Tunisia. The brotherhood octopus inside the judiciary disrupted 6,000 terrorism files.
} 


\section{Ambiguity and fallacy of the freedom of opinion}

The Tunisian constitution 2014 guarantees "freedom of opinion, thought, expression, information and publication". This freedom of expression, appeared since 2011, became more and more indirectly limited in determined cases: only when a person criticized severely the behavior of Ennahdha party or its leaders or its related religious extremist ones, he receives anonymous serious threats ${ }^{33}$; and when he does not respond to these threats, he is threatened with death, and if he does not respond and the government does not protect him adequately, he will be killed, as happened to the two known politicians, martyrs Belaid and El Brahmi. Moreover, successive Parliaments have not yet amended the provisions of the Penal Code, as well as those in other laws that criminalize speech, to bring them into line with the Constitution. Accordingly, Amnesty International Organization said in one of its report: Tunisian authorities should immediately stop using largely outdated, overly broad and repressive laws to prosecute people for exercising their right to freedom of expression online ${ }^{34}$.

As result of such serious repressive policy particularly against the media, media organizations have become constrained and not free to choose their own editorial line. For example El hiwar Ettounsi (Tunisian Dialogue) channel Ennahda was forced to retract a documentary broadcast about the disclosure of Ennahda's secrets and sources of funding ${ }^{35}$. Thus, particularly during the last years, the threat to freedom of expression has increased remarkably through various threats or the increase in the number of cases filed against workers in the media sector with the aim of intimidation and extortion ${ }^{35}$.

4. Other problems at the root of a false democracy were already evocated and explained in the precedents pages such as the lack of a rigorous financial control of parties and related associations during the elections periods.

On the basis of all these reasons the democracy, which was invented during decade of this poisoned revolution, is clearly a cosmetic political image rather than a reality: It is a false democracy founded on large networks of corruption that led Tunisia to its current catastrophic socio-economic situation. To get out of this dangerous

\footnotetext{
33 See : Amnesty International, 9/11/2020, Tunisia: Freedom of expression at risk as Number of Prosecutions Rises https://www.amnesty.org/ar/latest/news/2020/11/tunisia-freedom-of-expression-at-risk-as-prosecutions-rise/

${ }^{34}$ See: 13/2/ 2020 Business News (in Arabic). Between threats, intimidation and criminalization, the policy of suppressing media freedom is back. https://ar.businessnews.com.tn/

35 See: https://www.facebook.com/watch/?v=444538049530213 \& https://www.facebook.com/alarabiya.tunis/videos/444538049530213/
} 
situation, Tunisia needs to be entered in a crucial phase of struggle with the aim of carrying out comprehensive radical reforms, or rather putting an end to this poisoned revolution and calling for a new real one. Fortunately, this last possibility was confirmed with the emergence of the leader, Abir Moussi, who called for a new real revolution: the Enlightenment Revolution.

\section{Emergence of Abir's Enlightenment Revolution 2020}

At the end of the despaired decade of the poisoned Tunisian revolution 2011 a first real glimmer of hope appeared with the emergence of an exceptional leader, Abir Moussi, ${ }^{36}$ known by several qualities such as honesty, patriotism, courage, and competence that are difficult to find together in the same person. Because of her devotion to Tunisia and her willingness to defend it with courage and sacrifice, she was nicknamed the "Lioness of Tunisia". She was also called the "Iron Lady of Tunisia" given her strong and sustained attachment to her heroic struggle despite all the dangers facing her. Through her speeches and interventions in parliament, she stood out for what distinguished her from all current Tunisian politicians in terms of eloquence, honesty, courage, and political ability. Among these speeches I can quote that in a parliamentary session uploaded to the Tunisian Parliament's YouTube channel on 3/6/2020, where she said: "I am saying to you (parliament Speaker Rached Ghannouchi) that this is an accountability session, where you shall hear the bitter truth about yourself and the Tunisian people will hear the lies that you are spreading.... You are a part of the international organization of the Muslim Brotherhood. You admit this in everything you say and it appears on your official website... You were sentenced in absentia in 1991. How did you enter Tunisia on January 30, 2011? Why didn't you go to court when you entered Tunisia?... Why aren't you arrested when you entered Tunisia? Since you came back, you've been trying to falsify the history of this country. Since you came back, you've been spreading strife between Tunisians on the basis of falsely religious considerations. Since you came back, the political assassinations have emerged. You sanction the killing of the Tunisian people. You sanction the killing of people working for the security agencies. You sanction the killing of military personnel........ You have

\footnotetext{
${ }^{36}$ She is a Tunisian lawyer, holder of a master's degree in law and a DEA in economic and business law; she became a lawyer at the Bar of the Court of Cassation, the highest court in Tunisia. She is also president of the litigation committee and member of the national forum of lawyers of the Democratic Constitutional Rally (RCD) and secretary general of the Tunisian Association of Victims of Terrorism. She is the founder and the president of the Free Destourian Party (FDP) since 2016 and a Member of Parliament since 2019, and recently she appointed vice-president of the African Asian Women's Union for Africa and head of its branch in Tunisia.
} 
suppressed the judiciary and human rights. You lie to us every day with your falsified democracy, your deceitful accord, and your guidance on what to do and what not to do. We are waiting for you. You must leave this parliament. It's beneath my honor that we have you as speaker. It is beneath our honor to have, as Speaker of this parliament, a leader of the Muslim Brotherhood who is trying to spread a plan of darkness. In your books, you consider women as 'awrah' (They are not entitled to reveal any part of their body even their faces) and as 'sexual receptacles'. Women in Tunisia are free thanks to the great first President of the Tunisian Republic, Habib Bourguiba, and the Code of Personal Status. We shall remove you from your seat, through legal means. We shall take legal measures to remove you from power.........Tunisia will remain a secular and modern state. It will return to the Tunisians. It will remain in the moderate style of 'Habib Bourguiba'. Tunisia will maintain a moderate foreign policy. We will never let you toy will the fate of this country. This is not over. Let history record this! "37

As Abir Moussi is the leader of the party that represents the opposition against the majority of parties more and less involved in the corruption, her struggle for the national interest was difficult, strenuous and fraught with dangers. Moreover, at the end of the year 2020, with great courage and willingness she called for an Enlightenment Revolution (ER). The rapid support for her call by hundreds of thousands of Tunisians indicates that the feeling of necessity of such revolution is already existed in minds and hearts of all honest patriot Tunisians. This feeling comes as a reaction against what happened during the last ten years of catastrophic socio- economic decline, spread of corruption, emergence of political religious terrorism, and absence of trustworthiness and patriotism in the majority of successive governments' members. Through this ER, she aims to carry out radical reforms permitting, among others, to eradicate all kind of corruption and terrorism and, in turn, to develop a real democracy that, founded on the primacy of law and a new suitable Constitution, should lead to an enlightened socioeconomic and cultural progress. Her heroic struggle continued inside and outside the parliament: she informed Tunisians about details on the catastrophic current situation and the extent of the risks that threatens them, remembering of what happened during the decade under the dominance of the corrupt Ennahdha party and convinced them that it is time to enter into a real politico-moral intellectual revolution (ER) to save Tunisia.

\footnotetext{
37 Source: The Internet - "Tunisian Parliament on YouTube". Jun 03, 2020. https://www.memri.org/tv/tunisian-
} 
As stated above, during this decade, the freedom of expression is rather a paid propaganda more than a truth. Accordingly the continued Abir's criticism of Ennahdha led to her receiving death threats that were confirmed several times by the Terrorist Crimes Investigation Unit. She has enjoyed close security for several months, but then the tight security protection inside parliament was removed in response to a memorandum issued by Ghannouchi (parliament Speaker) and therefore she became intentionally threatened with her body and her life. This dangerous illegal decision made by Ghannouchi would be considered as his last solution after the failed of all his efforts to silence her voice inside the parliament, besiege her in the media outside, and mainly after seeing that her party (FDP) leads in the polls.

Despite all these grave circumstances, Abir did not give up and continued her struggle to oppose everything that was not in Tunisia's best interest, and owing to threats and the security deficit that characterizes the parliament assembly, she is obliged to present herself to the assembly on 4/5/2021 wearing a biker's helmet and a bulletproof vest. But as expected, after less than two months she has been physically attacked by two deputies allied with Ennahdha the Tunisia's Brotherhood ${ }^{38}$. Hence the United Nations called on the Tunisian authorities to take appropriate action against the attackers of political activists in order to protect the democratic process. Curiously, the President, Kais Said, confirmed that the violence in Parliament against Abir Moussi was planned three days ago ${ }^{39}$. Although the Parliament office decided that the two deputies will be delivered the maximum sanction, nothing was carried out. Therefore Abir Moussi said "Our confidence in the judiciary has been shaken by the impact of the lineup and policy of double standards, disregard for the constitutionally guaranteed rights of parliamentarians, and failure to protect the bodily inviolability of Tunisian women." She explained during a press conference that she would file a complaint with the International Criminal Court for torture and persecution of a part of the population on political and gender grounds 40 .

\footnotetext{
38 - See : Business News 30/06/2021. Sahbi Smara agresse Abir Moussi au Parlement https://www.businessnews.com.tn/Sahbi-Smara-agresse-Abir-Moussi-au-Parlement-,520,109685,3 \& - See Alarabiya News 5/7/2021. Muslim Brotherhood and violence in parliament https://english.alarabiya.net/in-translation/2021/07/05/Muslim-Brotherhood-and-violence-in-parliament ${ }^{39}$ See : meo (Middle East Online), 06/07/2021, The UN condemns the attack on Abir Moussa in Parliament. https://middle-east-online.com/

40 See : RT online 06/07/2921. Tunisia.. "Free Constitutional Party" brings "persecution of Abir Moussa" to international justice. https://arabic.rt.com/middle_east/1248863
} 
During 2021, the Abir's struggle out the parliament became more extend:

- She has organized numerous continuous speeches online to enlighten the Tunisian people and inform them of all the dangerous abuses that occur.

- She headed several demonstrations and a long peaceful sit-in in front of the entrance of headquarters of the branch of International Union of Muslim Scholars (IUMS) in Tunisia, demanding that it be closed, because it represents one of the major sources of the secret spread of obscurantism and terrorism. In fact, during the previous decade dominated mainly by the power of Ennahdha, this Tunisian IUMS branch was formed and obtained all official proof to act freely. This represents one of innumerable proofs that Ennahdha is strongly related to terrorism and obscurantism. In fact, the IUMS, founded in 2004 in Qatar and described as the supreme authority of the Muslim Brotherhood, was listed as a terrorist organization by various Arab countries ${ }^{41}$. After months of sit-ins and heroic struggle headed by Abir Moussi in front of the headquarters of this IUMS branch, the sit-in was broken up by force and violence and the headquarters was not closed, but an initial measure was taken: it is a formal alert to its officials, given the illegal abuse of their activities.

- She has also organized, in many regions of the country, several huge demonstrations and protests ${ }^{42}$ against the parliament and its government dominated by Ennahdha. These successive Abir's revolution huge protests, stimulating Tunisian people to do the first unorganized chaotic protest during which some of the headquarters of the Ennahdha were burned, have urged and encouraged the President of the Republic, Kais Said, in 25/07/2021, to activate Article 80 of the Constitution, as a state of exception, to freeze the parliament's activities and dismiss Head of Government.

Since then this decision sparked off a political critical analysis: First, as this Head of Government and the one before him were chosen by the President himself, their successive dismissal reflects a dual failure of choice that could be seen as a lack of political experience and absence of clear vision. Second, much confusion and controversy has taken place over the interpretation and the implementation of the Article 80. Here I will not discuss this issue but I want to note that the use of this article,

\footnotetext{
41 - Including Egypt, Saudi Arabia, the United Arab Emirates and Bahrain. Moreover the IUMS's leader Yusuf alQaradawi, named "the theologian of terror" by Irish media, is also banned from entering multiple countries, including the US, UK and France, despite holding a Qatari diplomatic passport.

- See Wikipedia, The free Encyclopedia https://en.wikipedia.org/wiki/International_Union_of_Muslim_Scholars

42 e.g. see Alarabiya News. 5/6/2021. Thousands of Tunisians protest against Muslim Brotherhood, Ghannouchi. https://english.alarabiya.net/News/north-africa/2021/06/05/Thousands-of-Tunisians-protest-against-MuslimBrotherhood-Ghannouchi
} 
even with some abuses, does not constitute a problem in itself because the majority of Tunisians have already demanded the dissolution of parliament and the overthrow of the government, but the problem is that this decision, particularly in its exaggerated state, could have two possible major goals: the first is that for which this Article 80 was established, it is to save the country from an imminent danger and to carry out this rescue within a specified period with a clear plan to return to the democratic situation after removing the danger; while the second undeclared dangerous one consists in enabling the president, who has absolute power in his hand, to achieve his personal political ambitions and to persist in the temporary special measure indefinitely.

'Ennahdha', and some other parties accused Kais' decision as a power grab, particularly after its confirmation, with exaggerated measures that effectively allow him to rule alone, by a presidential decree No. 2021-117. In addition of some moderate protests in favor or against this Kais' decision, a relatively more important one happened in 10/10/2021, in which thousands of Tunisians protested against Kais's seizure of almost total power and called for the cancellation of the coup to defend democracy and protect the Constitution ${ }^{43}$. On the other hand, in the beginning, the majorities of Tunisian population, including Abir's party supporters, accepted this Kais' decision with reservation and have not contributed to any protests preferring given the president the necessary time to do what he promised in the interest of Tunisia. In this way, despite her acceptance of this decision, Abir Moussi did not hesitate to criticize some abuses included in the presidential decree such as the exaggeration of the concentration of all powers into him during an unlimited period. Moreover, in response to indistinctness presented in some of his speeches she requested him to be clearer and do not make concealment of some facts, and to expedite the fulfillment of his promises.

Although the exceptional measures taken by the president have ended the direct political influence of Ennahdha its danger continues: (1) even after the passage of more than three months, its octopus of corruption, particularly that of corrupt instrumentalization of Islam carrying out through organizations and associations, is still working as usual beside the emergence of new associations that could be representatives of a convention between Tunisia and 'Qatar Fund for Development ${ }^{\text {,4 }}$, which seems

\footnotetext{
${ }^{43}$ See: Middle East Eye. 10 October 2021.Tunisia: Thousands protest against Kais Saied's power grab An estimated 5,000 people march in Tunis, facing reported police intimidation, to denounce the president's alleged 'coup'. https://www.middleeasteye.net/news/tunisia-protest-kais-saied-power-grab

44 See: Business News, 01 / 07 / 2021. Agreement of making a branch of 'Qatar Fund for Development' in Tunisia: Its objectives and legal abuses. https://ar.businessnews.com.tn/
} 
include legal abuses linked to possible hidden dangerous goals ${ }^{44}$, and (2) the trial of former governments members and Ennahda leaders involved in cases of corruption and criminality, has not yet begun. In other words the country has not yet been saved from the danger as required by the activation of the Article 80 .

In response to this awkward situation, many Tunisians are beginning to be disappointed by the unconvincing delay of political and judicial procedures they were waiting for; while others still cling to some optimism, considering this delay as a result of the difficult situation that the judiciary sector still suffers from, and therefore, the process expediting the consideration of thousands of accumulated and frozen cases requires more time. Another problem which is of concern to Tunisians is that the president is still ambiguous about his political program.

Despite this situation that began to frustrate the resolve, Abir Moussi has not stopped her struggle and under the slogan "Caravan of Enlightenment", her party organized a tour within several regions of Tunisia. It is a widespread enlightenment campaign aiming to enter in direct contact with Tunisians in order to determine their needs and problems, and to clarify what is hidden of the current political socioeconomic situation, how dangerous it is, and how much it needs the vigilance of all Tunisians. In addition, she has committed herself to continue the struggle aimed at eliminating the danger that still exists and confronting everything that would harm the Tunisian people, including attempts to plunge it into a dangerous political chaos.

\section{Conclusion}

In this study, I have carried out an anthropological analysis of major political events happened during the decade of the so-called Tunisian revolution 2011 aiming to reveal its truth and discuss the major issues related to it. Initially this revolution appeared to represent a new step of paradigm change in the history of political revolutions. But given that, after a decade, it has not accomplished any radical politico-moral change and therefore any of its major goals was achieved, it did not live up to the level of a real political revolution. This is due to the fact that this revolution was poisoned since its inception mainly thanks to secret interventions of some foreign countries, which have facilitated the rapid accomplishment of the first phase of the revolution, and then steered 
its second long stage on dangerous corrupt path in order to weaken the Tunisian State and, therefore, to carry out their political agendas in the region.

In fact although this revolution was started by young people who have no political and ideological affiliation, many opportunist politicians rode its wave and given a false revolutionary label to their parties. Some clues showed that 'Ennahdha' one of these parties, in a clear relationship with foreign countries, very likely got continually considerable secret funds. The use of these funds coupled with dissemination of religious misinformation, during the pre-elections period permitted this party to be the first to come to power. Since then, it has continued to use money to achieve dirty deeds such as controlling the media and many parliament members nonaffiliated to it, and secretly supporting and protecting those who perform the corrupt instrumentalization of Islam leading to terrorism and obscurantism. Moreover, it affords to not to apply, or interrupt, or circumvent laws that conflict with its interests, and to develop corruption through wide secret networks spread in most of the national institutions particularly in judicial and security sectors. This has ensured it permanent influence over the major joints of the State even if it does not have the highest representation in the Government.

All these major facts reflect the general profile of a political regime that represents a good model, showing how a false democracy could be built on extensive networks of corruption. After this despaired decade a first glimmer of hope appeared with the emergence of the wonderful leader 'Abir Moussi' who with a great courage and willingness called, since 2020, for an Enlightenment Revolution. Through this politicomoral-intellectual revolution, Abir Moussi aims to carry out radical reforms permitting, among others, to eradicate all kind of corruption and terrorism and, in turn, to develop a real democracy founded on the supremacy of law and a new rigorous suitable Constitution.

As Abir Moussi is the leader of the party representing the real opposition in a parliament where corruption prevails, her struggle for the national interest was difficult, strenuous and fraught with dangers, but she persevered thanks to her courage, sacrifice, and honesty coupled with a superb ability in eloquence. Hence, a popular wake up emerged through successive huge demonstrations and protests, organized and headed by Abir Moussi, against the ruling party 'Ennahdha'. This urged and encouraged the President of the Republic to order the suspension of parliament and dismissal of Head of Government. In other words, the heroic Abir's struggle is the basic element that 
prepared the end of the poisoned Tunisian Revolution 2011 with its corrupt regime, which was mainly fabricated and dominated by Ennahdha, the last dangerous stronghold of the World Brotherhood Sect.

However, she stressed the continuation of the struggle, because the new government has not yet saved Tunisia from the real danger: it is not yet started the trial of former governorate members and Ennahda leaders who are involved in cases of corruption and criminality, and not taken any action aimed at dissolution of all organizations and associations implicated in corruption and spreading obscurantism and political religious terrorism. Moreover, she is strongly engaged to confront everything that would harm the Tunisian people, including attempts to plunge it into a dangerous political chaos.

Therefore, the wonderful leader, Abir Moussa, with her exceptional courage, clarity of vision, sincerity in saying, devotion in work, wisdom and eminent political experience, remains the only current beacon carrying the hope of saving Tunisia from the consequences of ten lean years.

To eradicate the phenomenon of corrupt instrumentalization of Islam performed by the Ennahdha Brotherhood sect and other political religious ones and to prevent its re-emergence, I end this study by presenting the following recommendations.

\section{Recommendations}

\section{Recommendations regarding the concept of democracy and its application}

The term democracy is often used inappropriately, even in cases where democracy appeared clearly as a cosmetic political image rather than reality such as the Tunisian case during the period 2012-2021. In fact democracy, or rule by the people, is an ideal configuration that many world countries try to reach its highest degrees: It is not merely a question of election of rulers by the people but it needs a general deep restructuring including a correct and suitable Constitution that assure, among others, the primacy of law, the exercise of human rights, and a rigorous system of voting and elections.

* Some regulations applied in the electoral process need a radical review:

The permission of the use of huge of funds during the electoral process on the one hand and the secret use of other funds particularly from abroad and the lack of a strict supervision on the other hand, represent one of the most important problems that 
persisted even in the more democratic countries. In fact, although rules already established for settling such complicated problem, powerful interest groups or even big companies or billionaires can somewhat tilt the balance of the rivalry by supporting, via direct and secret ways, a party or a candidate. What happened in Tunisia, particularly in the first electoral process 2011 represents a good example of the secret use of foreign funds coupled to lack of effective and independent monitoring devices.

* Democracy implement needs a complete separation between State and religion:

It is true that among the foundations of democracy are the good morals that already deeply rooted in us, and generally religions came only to confirm them and encourage following them. But unfortunately all religions were, at least party, altered mainly by men of religion. For example democracy is in agreement with the principles and the essence of the real Islam, but it can never goes with current versions of Islam often transformed and more and less distorted and altered in the different sects of Muslims. Indeed, these versions are full of innumerable uncertain narrations, fibs, confusions, warps, and stupid injunctions with related invented laws that have nothing to do with the real unique Islam. Therefore, the democracy could not implement with success if State is not in a complete separation with religion (secularism). Accordingly designations such as 'democratic Islam' or 'Islamic democracy' are false with no sense and represent a contradiction in terms; moreover there is only one Islam that has nothing to do with policy. In other words we should not mix Islam and State policy because this leads to what I have called corrupt instrumentalization of Islam.

\section{Recommendations on the fight against the corrupt instrumentalization of Islam}

In my previous study (Chaabani 2017) I have already predicted the necessity of a politico-moral-intellectual wake-up to save Tunisia from its current catastrophic state, and I have envisaged that it could be accompanied by a gentle intellectual movement that I called "The Movement of Free Muslim Thought". Fortunately the Abir's ER 2020 came to be the wonderful representing of what I have predicted. As the major aims of this Abir's ER are clearly presented in the previous pages, I will only give some explanation on its moral and intellectual side that concerns the struggle against the corrupt instrumentalization of Islam that, based on immorality, corruption, obscurantism, threats, and terrorism, lead to a dictatorship declared or concealed under a false democracy. 
This struggle needs immediate measures to be carried out: First, accomplish a radical reform of the judicial and security sectors that ensures their safety from corruption and political infiltration. Second, implement the most effective and modern mechanisms in looking for who practices every forms of corrupt instrumentalization of Islam in their various stages: from who made public or secret speeches aiming to attract particularly young peoples, to who planed and / or supported, until who executes dirty and criminal acts. Third, close all organizations, schools and associations involved in the corrupt instrumentalization of Islam such as the headquarters of the branch of International Union of Muslim Scholars (IUMS) in Tunisia known for its secret spread of obscurantism and terrorism, and all related or similar associations with contrasting labels such as charitable associations and / or Qur'an teaching schools.

Although these urgent measures are necessary, they remain insufficient to resolve this great problem. Therefore, we must, at the same time, prepare long-term strategies that will achieve radical reforms at the level of sources of this problem. I can summarize these long-term strategies already detailed in Chaabani (2017) in the following recommendations:

- As I have explained in the previous pages, among methods used in corrupt instrumentalization of Islam that consists of making weird new words or misrepresenting others while manipulating their meaning: I have given some examples such as the term "Islami" (Islamist) and I have explained how political religious groups use these terms in attempt to disturb the thoughts of Muslim citizens and to facilitate their attraction to their cause. Accordingly, I recommend a carrying out national awareness-raising campaigns in which we present the goal of the use of all these strange terms invented by who implement the corrupt instrumentalization of Islam. Then, during this campaign, we urge people to do not use these terms at all levels such as in the media, journalism, and in cultural and political dialogues and writings. However, these terms would be replaced with another suitable terms: for example replace 'Islamist" by "political religious extremist' or 'political religious terrorist' (see other terms in Chaabani (2017), or reject others such as 'political Islam' because Islam is a unique religion that has nothing to do with policy; or 'Islamic left', which is a bizarre nomenclature that makes no sense beyond being funny showing the extent of the ignorance and naivety of those who put it as a new way to practice the corrupt instrumentalization of Islam (the trade in religion). In the case of the success of this campaign at the national level, it will find gradual acceptance at the international level. 
- Establishing, at the international and / or national level (s), real Great Research Center of Islam in which academic professors and young researchers will be recruited after a meticulous and strict competitive examination: they must be known by their good morals and their freedom of thought. Namely they must not be involved in any religious ideology and any commitment in political parties. Moreover, the academic professors must be Great Minds: eminent specialists at the international level in one of the scientific field (such as physics, mathematics, genetics.....) or in human and social sciences (such as Anthropology, Arab literatures, history, history of Islam....) and interested in the research on Islam subjects. In other words, we will eradicate one of the erroneous stupid rules established by narrow-minded opportunist Sheikhs who consider that only themselves can speak about Islam or do research on its different aspects; while the reality could be the contrary. In fact, these so called Sheikhs (men of religion) are often unqualified to accomplish any deep study that aims to establish new more convincing interpretations of Qur'an verses because they are ignorant of scientific fields; while data belonged to many principal sciences (sciences and human sciences) are already signaled within extraordinary Arabic rhetorical modes in the Qur'an text (Chaabani 2018; 2019; 2020). Even eminent scientific researchers are unqualified to interpret all Qur'an verses, but only verses on subject related to their specialty and ability, namely interpretation of only Qur'an verses related to a determined subject: this methodology is called in Arabic 'Al-tafssir Al maoudhou' $i$ ', interpretation by topic (Chaabani 2006). A deep review of the history of Muslim civilizations and that of the free thought in Islam could serve as a better platform for innumerable research subjects that would be started in these future Great Research Centers of Islam.

- A second necessity consists to do a radical review of the statutes and objectives of all Institutions of religion related to the study of the different aspects of Islam such as those belonged to Izzitouna University in Tunisia. Rigorous changes must be done also on the classic strategy of teaching and on the choice of teaching fields and related programs in these academic institutions. These changes must be in agreement with results and conclusions of the rigorous studies that will be accomplished in the future Great Centers of Islam. While waiting for the first batch of students graduated from these restructured institutions, current Imams of Mosques must be retrained and reselected.

- What is more, we must stop problems emanating from the so-called "Fatwa". In fact, this Arabic term means a simple opinion, but men of religion had given it an authoritarian meaning that has nothing to do with Islam. For them it means a religious 
legal opinion issued by one of them called "Mufti". I believe that it's a crying shame that in the 21 st century we accept that someone appointed by himself or by the government gives instead of God 'Allah' religious legal decisions on complex and thorny subjects. Although the current role of Mufti in Tunisia is limited and mainly symbolic, it would be replaced by that of a consultative national council composed by Great Minds expert in sciences and human sciences.

At the end, concerning the case of Tunisia, I believe in the vast capability of the great Tunisian people, particularly the brave patriot elites among thinkers, writers, journalists, academic researchers and artists, to fight intellectually all what falsely attributed to Islam and to contribute, through their intellectual and artistic product, to the reviving of the real essence of Islam. I think that such participations were already started softly and will appear more developed in the coming years in a gentle intellectual movement "The Movement of Free Muslim Thought" in Tunisia and in the entire Muslim World. This awakening, especially at the elites' level, is essential but remains insufficient as long as the top authorities do not support and achieve the most prominent elites' recommendations after ascertainment of their wisdom and efficacy. At this political authority level in Tunisia, currently things are unclear and our hope remains for a future sponsored by the great leader Abir Moussi who represents a blessing from God's grace sent to save Tunisia from those who perform the corrupt instrumentalization of Islam.

In fact one of the principles of Islam is the human dignity and freedom including the freedom of thought. This is clear through deep rigorous interpretations of innumerable Qur'an verses. For example in a previous study (Chaabani 2019) I have determined in Qur'an an exceptional dynamism and defined it as the fact that the Qur'an content has the ability to be virtuous, valid and worthwhile for all humans living at all times and everywhere. In this way, I have detected three possible major dynamic processes peculiar to Qur'an one of which concerns the freedom of thought: among others, it represents the fact that for each vital social issue presented in the Qur'an, Allah does not provide an absolute legislative rule that Muslims must implement blindly as much as He would intend to familiarize Muslims to evaluate and compare advantages and disadvantages between different approaches of a given issue; and therefore Muslims preserve the flexibility to choose what is good at both the personal and the societal levels at a given epoch. In other words God 'Allah' incited us to think, analyze and compare good and bad, and then make a decision freely after making sure that it does 
not harm either our person or our family or society as a whole. This is in contradiction with what was fabricated by men of religion in their Shari'a and Fikh books, or in their ideologies, aiming to enslave mentally the higher number of Muslims.

This freedom of thought cannot be separated from the human freedom as a whole, the mental-physical freedom, that gone, throughout human history, by continual attempts of violation by men themselves such as some of who have power. Hence, several Great Minds, known by their remarkable humanism, down the ages, had expressed their astonishment towards this sort of abuse such as Omar ibn al-khattab (636-644), one of the most powerful and influential Muslim caliphs in history, through his saying: "Since when do you have enslaved people, although their mothers were procreated them free?". Or, later in 1762 Jean-Jacques Rousseau, known as one of the most influential thinkers during the 18th-century European Enlightenment period, wrote "Man is born free and everywhere he is in chains". Later on, the great Tunisian poet Abu al-Kacem Chabbi (1909-1934) described this freedom in many of his wonderful verses such as where he said: You are created free like a breeze spectrum and like the dawn in its sky ..... Why do you accept the ignominy of restrictions and to bend over for those who enslaved your forehead? (See the poem in Arabic in Chabbi 2011).

Conflicts of Interest: The author declares no conflict of interest

\section{Rreferences}

Chaabani H. 2006. Facts of the Human Creation under the lights of Sciences and holy Qur'an " (in Arabic: Sounanou khalq al-Inssan tahta adhoua'i al-Ilm oua nour alQur'an). Les Imprimeries Reunies, Tunis, Tunisia. ISBN: 978-9973-61-201-4.

Chaabani H. 2017. The Tunisian Revolution "The Free, Youth Revolution" from an Anthropological Perspective. International Journal of Modern Anthropology 10: 14 48. DOI: http://dx.doi.org/10.4314/ijma.v1i10.1

Chaabani H. 2018. New insights into human early embryonic development: a particular theoretical study. International Journal of Modern Anthropology 2(11): 14 - 46.

DOI: http://dx.doi.org/10.4314/ijma.v2i11.1 
Chaabani H. 2019. The miraculous dynamism of the Qur'an: An example of a modern reading reveals a DNA designation International Journal of Modern Anthropology. 2 (12): 15 - 61 DOI: http://dx.doi.org/10.4314/ijma.v2i12.1

Chaabani H. 2020. New insights into the processes of biological evolution and human reproduction provided through a dialogue between science and Qur'an International Journal of Modern Anthropology. 2 (13): 20 - 66

DOI: http://dx.doi.org/10.4314/ijma.v2i13.1

Chabbi A. 2011. “Aghani al-Hayet”. Manchourat Dar Al-Chabeb. Tunis, Tunisia.

Chesnot C. and Malbrunot G. 2013. Qatar, les secrets du coffre-fort (Paris: Michel Lafon), p. 198; http://www.mag14.com/national/40-politique/1785-la-tunisie-et-les$\underline{\text { secrets-du-coffre-fort-qatari.html }}$

Gallien M. \& Werenfels I. 2019. Is Tunisia Really Democratising? Progress, Resistance, and an Uncertain Outlook. Comment n ${ }^{\circ} 13$, Stiftung Wissenschaft und Politik (SWP). German Institute for International and Security Affairs. https://www.swp-berlin.org/fileadmin/contents/products/comments/2019C13_gallienwrf.pdf

Grosser F. 2016. Political Revolution. Internet Encyclopedia of Philosophy (IEP) (a peer-reviewed academic resource). https://iep.utm.edu/pol-rev/

Haller D., and Shore C. 2005. Corruption: anthropological perspectives. Londres: Pluto Press, 2005

Higgins A.C. 2004. "Kharijites, Khawarij". In Martin, Richard C. Encyclopedia of Islam and the Muslim World v.1. Macmillan. p. 390.

Kant I. 2006a, “Toward Perpetual Peace: A Philosophical Sketch" [1795/96], in Toward Perpetual Peace and other Writings on Politics, Peace, and History, ed. P. Kleingeld, trans. D.L. Colclasure, New Haven: Yale University Press, 67-109

Kant I. 2006b, “An Answer to the Question: What is Enlightenment?" [1784] in Toward Perpetual Peace and other Writings on Politics, Peace, and History, ed. P. Kleingeld, trans. D.L. Colclasure, New Haven: Yale University Press, 17-23.

Kaush K. 2013. 'Foreign funding' in post-revolution Tunisia. AFA, FRIDE (is a European think tank for global action). Hivos. ISSN: 2172-5829 (Print), ISSN: 21725837 (Online). https://www.files.ethz.ch/isn/167265/WP_Tunisia.pdf

Kirkpatrick D.D. 2011. Financing Questions Shadow Tunisian Vote, First of Arab Spring. The New York Times (Oct. 22, 2011). https://www.nytimes.com/2011/10/23/world/africa/tunisia-election-faces-financingquestions.html? r=1 
Kortas M. 2013. On the Edge? Trafficking and Insecurity at the Tunisian-Libyan Border. Small Arms Survey, Graduate Institute of International and Development Studies, Geneva.

https://assets.publishing.service.gov.uk/government/uploads/system/uploads/attachment _data/file/268793/SAS-WP17-Tunisia-On-the-Edge.pdf

Medini T. 2014. The Sacred Alliance 'between Qatar, Ennahdha and the blasphemous movements'. 145 El Wihdha El ISlamia.

https://www.wahdaislamyia.org/issues/145/tmadini.htm

Morris S.D. 2011. Forms of corruption. Forum, CESifo DICE Report 2/2011

Nye J. S. 1967. Corruption and Political Development: A Cost Benefit Analysis, American Political Science Review 61(2): 417-27.

Persson T., Tabellini G., Trebbi F. 2003. Eectoral rules and corruption. European Economic Association https://watermark.silverchair.com/jeea0958.pdf

Schafer I. 2015. The Tunisian Transition: Torn Between Democratic Consolidation and Neo-Conservatism in an Insecure Regional Context. PapersIEMed. Publication and coordination: European Institute of the Mediterranean. ISSN: 1888-5357.

https://www.diegdi.de/uploads/media/Tunisian_Transition_EuroMeSCo_Paper_25_Isabel_Schaefer.pdf

Talbi M. 2015. Tajdid al-Fikr al-Islami: Dalil al-Moulim al-Qur'ani. Fansi liattibaa. Tunis, Tunisia.

Talbi M. 2016. Tajdid al-Fikr al-Islami: Khdhiat al-Haquiqua. Fansi liattibaa. Tunis, Tunisia.

Yerkes S. and Muasher M. 2017 (October 25). Tunisia's Corruption Contagion: A Transition at Risk. Carnegie Endowment for International Peace.

https://carnegieendowment.org/2017/10/25/tunisia-s-corruption-contagion-transition-atrisk-pub-73522

Pr. Dr. Hassen Chaabani was born the 07 / 09 / 1947 in Tunis (Tunisia). He is Full Professor and former Director of research unit at Monastir University. He is the Founder and the President of the Tunisian Association of Anthropology. He is the Founder and the Editor-in-Chief of the International Journal of Modern Anthropology. Specialist in Human Genetics and Anthropology, he wrote dozens of academic articles, two books and several book chapters. In 2014, he was awarded the honorary title of Professor Emeritus. 
To cite this article:

Chaabani H. 2021. Abir's Enlightenment Revolution is the basic element leading to the end of the corrupt regime resulting from the poisoned Tunisian revolution 2011.

International Journal of Modern Anthropology. 2 (16): 509 - 547

DOI: http://dx.doi.org/10.4314/ijma.v2i16.1

\section{(C) $\oplus \Theta \Theta$}

This article, as all articles published in this journal, is under The Creative Commons Attribution: Attribution-NonCommercial-NoDerivatives 4.0 International (CC BY-NC-ND 4.0).

https://creativecommons.org/licenses/by-nc-nd/4.0/ 